picked up a good sub-triangular wedge-shaped implement. Further search produced a second implement, a good trimmed flake, and a few simple flakes. The worked flints in the Hertford gravel are however so rare that the search for them is the most hopeless task conceivable. There is not more than one flake in 500 tons, not one implement in 5000 tons of gravel. The gravel from Ware is also brought to the east of London for ballast, and I happened last year to mention the fact of my dis. coveries to Mr. J. E. Greenhill, the Principal of a school near Hackney Downs. Mr. Greenhill at once not only searched himself, but set his pupils to look over the Ware gravel, then laid down in large quantities near Clapton, with the result that a large broken ovate implement was found and several flakes. I also found a large and beavy "slice" flake with numerous facets on its worked side in the same gravel. Mr. Greenhill's success caused me to look carefully over a similar lot of gravel from Ware, laid down near Victoria Park. In this I found a sub-triangular implement and three flakes. I have also found a large greatly abraded flake in the Amwell gravel at Amwell. Else where in east and north-east London I have looked over thousands of tons of Hertford and Ware gravel without decisive result. A week or two ago, however, as my younger son was returning home through Finsbury Park, he picked up a good scraper-like implement in the gravel (presumably from Hertford), just thrown on to the road inside the park. On hearing of the discovery I at once went to Finsbury Park and looked carefully over all the recently thrown down material, but with no further result. I have visited the different pits at Hertford, Ware, and Amwell several times, but there is never enough gravel exposed (considering the extreme comparative rarity of the implements and flakes) to give one chance of finding an implement. I have found in the pits several simple flakes, with the cone of percussion, and that is all. At what depth the implements occur in the gravel I do not know, but that implements really do come out of the high gravels overlooking Hertford and Ware I think there can be no doubt. Reference was made by me to these implements at the Anthropological Institute three years ago, when two or three specimens were exhibited by me.

125, Grosvenor Road, Highbury, N.

TITHITON G. SMITH

\section{Sound of the Aurora}

WiTh every respect $f$ or the ability and acuteness of the late Sir John Franklin and his companions, I do not think it conclusive, as Mr. Rouse seems to do, that because they heard no sounds " with the aurora borealis" (NA'TURE, vol. xxiii. p. 556), no sounds are produced by it.

All Indians, both on the shores of Hudson's Bay and near Bear Lake, and the Eskimos on many parts of the coast, asser positively that the bright, varying, flickering, ${ }^{1}$ and rapidlymuving auroræ do produce sound. The senses of hearing and smelling in the Indian and Eskimo are far more acute than in the civilised man; and both sounds and smells which to the latter are not perceptible are perfectly so to the more sensitive auditory and olfactory organs of the savage.

The theory that " the attractive force of the aurora is increased within a certain limit as its rays proceed southward" is scarcely borne out by my experience.

When wintering at Fort Hope, Repulse Bay, in 1846-47 and $1853-54$, lat. $66^{\circ} 32^{\prime} \mathrm{N}$., the result of my observations was, as far as I can discover, exactly similar to that of Parry in 1824-25 at Port Bowen in lat. $73^{\circ} 15^{\prime} \mathrm{N} ., 400$ miles further north and fifty miles west of Fort Hope : at both no effect was produced on the magnetic needle.

At Repulse Bay, and it may have been the same at Port Bowen, the character of the aurora was perfectly different from that generally seen at Great Bear Lake, which acted so powerfully on the needle, the former being almost always of a uniform pale yellow or straw colour, with little rapid motion, whereas the latter was generally flashing, flickering, rapidly moving, and of diverse hues.

One peculiarity of the aurorx observed at Repulse Bay may be worthy of notice: they were chiefly seen to the magnetic south-that is south $62^{\circ}$ east true-usually in the form of an arch rather low down-and I may add that in that direction at a distance of thirty or forty miles from our head-quarters a large extent of sea is kept open all winter by strong currents. The

I I borrow this most appropriate term from Prof. Stokes, F.R.S., \&c., of Cambridge.
Eskimos of Repulse Bay do not say much about the aurora beyond expressing a belief that it is the spirits of their dead visiting each other in the heavens.

It is probably a matter of little or no importance in a question of this kind, but $\mathrm{Mr}$. Rouse has given the latitudes of the southern shores of Great Bear Lake from 90 to 200 miles too far north.

Fort Franklin, where Franklin made his chief observations, is situated in latitude $65^{\circ} \mathbf{1 2} \mathbf{2}^{\prime} \mathrm{N}$. at the extreme south-west of Great Bear Lake, whereas Fort Confidence, where Sir J. Richard on and I made ours with like results, is at the extreme north-east of the lake in lat. $66^{\circ} 54^{\prime} \mathrm{N}$., the stations being $15{ }^{\circ}$ miles distant from each other.

It is perhaps not being too sanguine to hope that in this perio 1 of marvellous discoveries, some instrument may be-if not already-invented, with the aid of which one may be able to decide the question satisfactorily as to whether the aurora in any form does or does not produce s sund.

$$
\text { 4, Addison Gardens, April I6 }
$$

\section{THE SCIENTIFIC PRINCIPLES INVOLVED IN ELECTRIC LIGHTING ${ }^{\mathrm{I}}$}

II.

\section{Lectures III. and IV.}

A LL machines for the conversion of mechanical work into electricity are founded on Faraday's great discovery of the induced current derived from the relative motion of a magnet and a coil of wire. They are either continuous-current or alternate-current machines. From the continuous-current machines of Pixii in 1832 and Saxton and Clarke in 1835 and 1836 , we pass to Wheatstone's introduction in 1845 of electromagnets in place of permanent magnets to produce the magnetic field. In I854 Werner Siemens and Halske introduced the Siemens armature, in which the coil is wound longitudinally in a groove. In 1854 Hjorth patented an improved magneto-electric battery, in which the currents induced in the revolving armature pass round the electromagnets and produce the magnetic field. This is the principle of the dynamo-electric machine, which was afterwards rediscovered by Siemens and by Wheatstone simultaneously in 1867 , when on the same evening their two papers were presented to the Royal Society.

Then followed the Gramme armature, in which coils of wire are wound in sections all in the same direction round a ring; each section, when a currẹnt is flowing through it, may be regarded as an electro-magnet, and its principle of action is clear at once from the principles of Arago and from Lenz's laws for induced currents.

In dynamo-electric machines the external work in the electric are is proportional to the square of the curront, and is also proportional to the number of turns of the armature per minute.

Any disturbance in the resistance of the arc reacts on the electro-magnet, altering the strength of the magnetic field, thereby increasing the disturbance; this is the great disadvantage of dynamo-electric machines as compared with magneto-electric machines, where the magnet is either a permanent magnet or is excited by means of a separate current. Wilde, in 1863 , employed a separate continuous current machine to give a permanent magnetic field, and made the armature of the second machine to revolve in this magnetic field. In alternate-current machines there is no commutator for making the current continuous, but the currents from the coil are collected and sent through the external resistance in opposite directions for every half-turn of the armature. The Alliance magneto-electric machine was the first of these, which was converted by Holmes into a continuous-current machine, and was by him first used in $185^{8}$ to produce the electric light for lighthouse illumination. He afterwards again converted his machine into an alternate-

\footnotetext{
I By Prof. W Grylls Adams, F.R.S. Continued from p. 582 .
} 